\title{
Political Cycles' Influence on Inflation and Unemployment ${ }^{4}$
}

\author{
Article history: \\ Received: 17 March 2015 \\ Sent for revision: 18 March 2015 \\ Received in revised form: 21 May 2015 \\ Accepted: 27 May 2015 \\ Available online: 2 July 2015
}

\begin{abstract}
The aim of the research is to show the relationship between political parties and voters and its impact on economic situation in the pre and post-election period. The paper points out the interaction between economics and politics, the behaviour of an individual in the economic and political market and analyses the economic models that study the response of voters to different political programmes. An overview of all political elections in the Republic of Serbia since 2000 and the inflation and unemployment rates during the same period is also provided in order to confirm the hypothesis that inflation and unemployment in the pre-election period are in the function of political interests, while in the post-election period they return to their initial level.
\end{abstract}

Keywords: political business cycle, voters, inflation, unemployment, political parties.

\section{Uticaj političkih ciklusa na inflaciju i nezaposlenost}

Apstrakt: Cilj istraživanja je da ukaže na relaciju između političkih stranaka i birača i njene posledice na stanje u privredi u predizbornom i posleizbornom periodu. Rad ukazuje na interakciju ekonomije i politike, ponašanje pojedinca na ekonomskom $i$ političkom tržištu $i$ analizira ekonomske modele koji proučavaju reagovanje glasača na različite političke programe. Osvrt na

\footnotetext{
${ }^{1}$ University of Nis, School of Economics

${ }^{2}$ University of Nis, School of Science and Mathematics

3 University of Nis, School of Economics, tamara.radjenovic@eknfak.ni.ac.rs

${ }^{4}$ The paper is a result of research within projects 179066 and III 42006, funded by the Ministry of Education, Science and Technological Development of the Republic of Serbia
} 
Rakić B., et al.: Political Cycles' Influence on Inflation and Unemployment

političke izbore u Republici Srbiji u periodu od 2000. godine, kao i kretanje stopa inflacije i nezaposlenosti tokom istog perioda je prikazano sa ciljem da se potvrdi hipoteza da se inflacija $i$ nezaposlenost u predizbornom periodu stavljaju u funkciju političkih interesa, da bi se nakon izbora vratili na svoj prvobitni nivo.

Ključne reči: politički poslovni ciklus, glasači, inflacija, nezaposlenost, političke stranke.

\section{Introduction}

The economy of each country inevitably bears the stamp of political events, which reach their own culmination and have the strongest effects on the economy in the time of political elections. Political parties, able to influence a country's economy in the pre-election period and led by the goal to win the elections, try to create economic environment by using economic measures that would "embellish", at least in the short-run, the economic reality and persuade as many voters as possible to vote for that political party.

Decision-making on a political level greatly contributes to the creation of the economic policy of a country. In both political and economic process, individuals are led by their own interests. Among various alternatives, they choose the one which will contribute to the achievement of their goals in the best possible way. In addition, they expect the benefit from the chosen alternative to be greater than possible expenses.

On the so-called political market, the possibility of election from voters' point of view amounts to the choice among political parties. In their eagerness to capture votes, political parties proclaim various political programmes, which should lead to general prosperity of the country by means of numerous political and economic goals. The way of setting policy and formulating goals is subordinate to the aspiration that it should be acceptable to as many people as possible.

In this paper, the relationship between economics and politics is analysed through economic models; the influence of political parties on defining macroeconomic policy by means of their influence on inflation and unemployment rates is also taken into account; the reaction of voters is analysed as well. The way voters react on political campaigns and the way political parties use those campaigns in order to win the largest possible number of voters is researched. 
Rakić B., et al.: Political Cycles' Influence on Inflation and Unemployment

\section{Interdependence between Economics and Politics}

The connection between economics and politics is already well known, but special attention has been paid to their interdependence with the development of the public choice theory in the last few decades.

The connection point between politics and economics is an individual whose behaviour does not differ a lot regardless of whether political or economic activities are in question. Taking into account that altruism is very rare, personal interest is what triggers individuals to do or not to do certain activities (Tollison, 2004, 281-284).

Unlimited needs and wishes combined with limited resources available for their attainment motivate individuals to allocate those resources in the best possible way, by choosing the alternative which offers the maximum benefit. Namely, both benefits and expenses of each alternative are evaluated through cost-benefit analysis and marginal income of the selected one has to be greater than marginal expenses.

As participants on political market, voters who are led by their own interests, place their confidence in the political party that will realize their interest in the best possible way and provide the greatest benefit. On the other hand, political parties strive to maximize the ballot in order to win political elections. By means of political parties and their functions in them, politicians endeavour to accomplish their own interests and formulate their policy (Drašković, 1998, 214-215). According to Gavious and Mizrahi (2002), in order to maximize political efficiency, politicians chose to invest in the group that will provide them maximal support at the elections and increase their chances to be reelected.

Quite new science, public choice theory, is based on individual interest, both in economic and political market. Duncan Black tried to explain political market in 1948 by using economic theories and models, and, above all, the rule of public decision-making, researching political processes, which led to creation of macroeconomic solutions and economic policy (Rowley, 2004, 3). In his work, which represented a scientific counterbalance of its kind to his economic theories about competing market balance, he explained rational decision-making concerning political elections. Namely, one suggestion can bring the largest number of votes in comparison with all the rest, if it affects the "median voter", which creates an opportunity for making a balance.

Apart from the authors who dealt with it later, at the beginning of this theory, Buchanan and Tullock made a significant contribution in their work The Calculus of Consent in 1962 by encouraging political scientists, who supported the majority rule thesis, to think (Rowley, 2004, 3-4). 
Buchanan and Tullock pointed out that, during voting, individuals are guided by the principle of minimizing total expected external expenses and their expenses of participation in decision-making as collective action (Buchanan, 2004, 60-66). Additionally, they contributed to studies on this topic by discovering that market errors, such as monopoly, public goods, negative externalities, asymmetric information and moral hazard, are more evident on political than on other markets.

Various papers written on this topic point out in numerous ways that "politics is a complex system of exchange among individuals in which they are collectively striving to accomplish their own private aims because they cannot accomplish them by means of simple market exchange“ (Drašković, 1998, 215).

Furthermore, the interaction between economics and politics can be envisaged by researching the phenomenon of economic and political freedom. Economic freedom is related to the private market where individuals make decisions on their own about their exchange, while political freedom includes the right to vote and civil rights. The right to vote means that voters choose political leaders on their own. Civil rights refer to the individuality of voters to make their own decisions as long as they do not endanger other people's rights.

However, political freedom once established can show the tendency of economic freedom violation (Wu \& Davis, 2004, 163-171). Namely, individuals who enjoy certain political rights can affect economy through democratic forms. They may lead to the redistribution of someone else's wealth and limit economic liberty by intruding private market, restricting competition, manipulating prices, etc.

\section{Overview of Political and Economic Models}

The model of political and business cycle analyses the relationship between economics and politics by using economic and/or political techniques. In general, this model provides the answer to the following question (Frey, 1984): How does economic situation influence voters' attitudes to government's policy success, and thus their decision whether or not to support the government at next elections?

The key determinant of political and economic cycles is voters' myopia, which enables political parties to adjust their policy before and after the elections (Rogoff, 1990, 21-26). Therefore, government increases money supply and achieves the growth of GDP and employment rate. Actuated by positive economic actions, voters are predisposed towards that political party, 
regardless of the fact that after the elections the inflation rate will rise and unemployment and GDP will go back to their original level. However, this theory has two drawbacks. First, elections are perfectly anticipated so that the pre-election increase in money supply would not have real effects. Second, macroeconomic policy is set before the elections, so voters actually vote for the party based on the promises made for post-election period.

Various political and economic models were developed for researching how voters decide to support a political party, i.e. the way political parties are trying to predispose them. The early economic models which dealt with the correlation between political and economic indicators are presented in Table 1.

Table 1. The Basic Indicators in Early Economic Models

\begin{tabular}{|l|c|c|c|l|}
\hline \multicolumn{1}{|c|}{ Models } & $\begin{array}{c}\text { Dependent } \\
\text { variables }\end{array}$ & $\begin{array}{c}\text { Economic } \\
\text { indicators }\end{array}$ & Political indicators & \multicolumn{1}{c|}{$\begin{array}{c}\text { The basic economic } \\
\text { results }\end{array}$} \\
\hline $\begin{array}{l}\text { Goodhart } \\
\text { and } \\
\text { Bhansali } \\
(1970)\end{array}$ & $\begin{array}{c}\text { Governmental } \\
\text { popularity }\end{array}$ & $\begin{array}{c}\text { Inflation } \\
\text { Unemployment }\end{array}$ & $\begin{array}{c}\text { The effect of the } \\
\text { election cycle }\end{array}$ & $\begin{array}{l}\text { Inflation and } \\
\text { unemployment together } \\
\text { are both very } \\
\text { significant in predicting } \\
\text { popularity }\end{array}$ \\
\hline $\begin{array}{l}\text { Mueller } \\
(1970)\end{array}$ & $\begin{array}{c}\text { Presidential } \\
\text { popularity }\end{array}$ & Unemployment & $\begin{array}{c}\text { The expenses of } \\
\text { election campaign } \\
\text { "Gathering around } \\
\text { the flag" } \\
\text { War }\end{array}$ & $\begin{array}{l}\text { Asymmetrical effects: } \\
\text { High unemployment } \\
\text { rate - punishment of } \\
\text { the President; } \\
\text { Low unemployment } \\
\text { rate - without an award }\end{array}$ \\
\hline
\end{tabular}

Note: Election cycle - the change in popularity of the government throughout their mandate; "gathering around the flag" - the hypothesis which shows that greater support can be achieved for the president if there is the inclusion in international events; War - the hypothesis which shows that the support for the president will be weaker if the country is involved in a war

Source: Evans, J. A. J. (2003), Voters and Voting: An Introduction, London UK: SAGE Publications, p. 127.

As we can see from Table 1, the economic indicators used in these models do not always have the same effect on economy. On the other hand, Goodhart and Bhansali observe the linear connection between inflation and unemployment, Mueller underlines their asymmetry where higher unemployment leads to unpopularity, while lower unemployment leaves politicians without any benefits. Furthermore, Goodhart and Bhansali emphasize the component of inflation, whereas Mueller does not include it in his own research.

These early models served as a basis for the further development of aggregate economic models, as well as the economic model from an 
Rakić B., et al.: Political Cycles' Influence on Inflation and Unemployment

individual's perspective. According to Evans (2003, 129-140), there are four aggregate economic models:

- The existence of the government's responsibility

- The elements of the government's responsibility

- The decomposition of the national model

- The informedness of voters

\subsection{The existence of the government's responsibility}

This model is based on the premise that people see the government, i.e. the ruling political parties as responsible for the economic situation. Hence, based on the analysis of the pre-election economic situation, the existing government is awarded or punished.

However, there is an issue with the government's responsibility determination depending on the way it is formed. If it is formed only by the members of the ruling party, then the situation is quite clear, since all the responsibility for good or bad results is ascribed to them. But, if the government is formed by members of a large number of parties, it is difficult to determine and allocate the responsibility among them.

For example, if the government consists of a coalition of several parties, and citizens are dissatisfied with their work and vote for the other party in coalition, the government as a whole still has the same support. Besides, an opposition party in charge of a legislative body can occasionally strongly influence the economic policy, thus blurring the responsibility. Studies show that in countries with clearly determined responsibility for economic policy, connection between economic indicators and political voting is stronger, than in countries where it is difficult to determine responsibility (Evans, 2003).

\subsection{The elements of the government's responsibility}

If the complexity of the relationship between inflation and unemployment is taken into account, it is clearly impossible to reduce both indicators at the same time. Therefore, political parties choose to regulate only one indicator and emphasize it in their programmes.

The orientation to solving one problem would mean that they are responsible only for accomplishment of that aim. Therefore left-wing parties will take responsibility for reduced unemployment rates, whereas their responsibility for inflation will not exist. The opposite situation is with right-wing parties. However, some studies show that the responsibility is not only taken for one economic indicator, thus leading in some cases to the loss of a certain 
Rakić B., et al.: Political Cycles' Influence on Inflation and Unemployment

number of votes at the elections (e.g. the 1986 elections in France) (Evans, 2003).

\subsection{The decomposition of the national model}

This model is based on the premise that unemployment rates are not equal in all regions. Countries with expressed regional underdevelopment face higher unemployment rates in border areas, underdeveloped areas, those far away from important cities, etc.

Unemployment does not affect all regions in a country in the same way and hence does not produce the same effects on the government's popularity and voters' attitudes at the elections. The government will lack support in regions with this problem, if its focus is on solving other economic problems.

\subsection{The informedness of voters}

Public choice theory made it clear that voters' motive is the key determinant of political market balance. Opposition parties strive to incorporate those motives in their political programmes in order to predispose a median voter.

According to Paldam (2004, 49-59), typical voter's behaviour can be presented in the following way:

- $\quad$ they react to unemployment and inflation change above all, but they have poor knowledge about (macro)economics;

- $\quad$ myopia - voters' time horizon is short. The political events not older than a year affect voters and that is why the greatest number of political and economic actions happens in the pre-election year. However, economic crises and other negative events, which may weaken economy and are out of the current government's reach, are sometimes not good enough in voters' eyes and reduce government's chances to be elected again.

- retrospective - voters react more to past events than their expectations;

- $\quad$ in the majority of countries voters care not only about their prosperity, but also about the national economy;

- $\quad$ voters punish government for a poor economic situation to greater extent than they would award it for good economic situation.

The way how individuals see economic situation, as well as its most important elements, varies. The fact is that a connection between economic indicators and political popularity exists. However, if the government would be punished 
for bad political results, then it would not be re-elected at next elections, because it is difficult to completely achieve set goals and all voters cannot be satisfied with their financial situation. Nevertheless, this does not happen because all individuals do not react in the same way. This fact does not reduce the importance of the aggregate economic models since they are very important for predicting the elections results, but they cannot track variations on the individual level.

There are two paradoxes in the aggregate economic models which individual economic models can use. Firstly, voters should make rational decisions directed towards future benefits - national and individual. Secondly, the connection between economic indicators and political popularity implies that voters are well informed for a short period of time. Studies show that an individual has valid information about unemployment rates, but that is not the case when it comes to inflation and the balance of payments (Evans, 2003).

\subsection{The economic model from an individual's perspective}

While deciding what party to vote for at elections, individuals can base their decisions on future expectations or the analysis of previously achieved goals.

Retrospective voters will support the government if they are satisfied with achieved economic results. Otherwise, they will vote for other parties. According to Martinez (2009), voters re-elect the incumbents only if they expect them to have good performance in the future, and since incumbents want to be re-elected, they focus on improving their performance. However, voters can only assess the results of the ruling political parties and evaluate their work, whereas for opposition parties they can just guess what results they would have if they were part of the government.

Prospective voters base their decisions on their expectations. They compare political programmes of several parties and choose one that will bring them the greatest benefits. The fact that selection in this case is based on trust in a political party and not on the precise data about achieved goals, puts retrospective voters in a better position since they have the exact data and not only assumptions.

However, the practice confirms that voters cannot make decisions only based on past events or their current expectations. Simultaneously, they analyse and assess latest economic changes, but also evaluate which political parties will bring them the greatest benefit if they are in power (Evans, 2003).

Past or future events can be analysed from the individual perspective or on the national level. Macroeconomic indicators, usually used for evaluation of government's efforts, suggest that economic situation is prioritized. But, the most important is how voters see those indicators i.e. whether voters put the 
country's interests before their own financial interests. What will happen in situation when, during the pre-election period, economy prospers but some citizens lost their jobs or left without possibility to find another job, thus affecting their financial situation? Will those individuals be led by their own dissatisfaction and "punish" the ruling party by not voting for them at the elections or will they take into account general financial prosperity in the country?

Apart from voters' individual characteristics, which are hardly predictable and manageable, the answers on the above mentioned questions depend on a country where the elections take part. In EU countries, voters put national interests in front of their financial interests, even though they know that some future political decisions will affect their budget. They do this not because they care about their fellow citizens' standard, but because they are aware that the prosperity of their country has a long-term nature and leads to the improvement for all citizens. In contrast, an individual's financial benefit can be only short-termed if it is not based on real economic grounds of the whole economy (Evans, 2003).

The analysis of key determinants of the above mentioned models suggests that government's fundamental role is to properly manage the country and the economy, as well as to implement proclaimed policy in the best possible way. The government's popularity varies with upturns and downturns in economic performance (GDP, inflation, unemployment, the balance of payments, foreign currency liabilities etc.), and therefore tests of this popularity show how successful the government is in economy management.

\section{The Political Business Cycle}

In the initial stages of the mandate, the population performs evaluation by comparing the promises with what has been achieved. The least they expect is full financial prosperity of the country, which is actually what was promised by every political party during the pre-election period.

Guided by the desire to win elections, political parties in the pre-election period use macroeconomic policy that will quickly lead them to that goal. In 1971 Kramer was the first who presupposed a link between economics and voting at the presidential elections (Mueller, 2004, 39). After the studies were conducted in the U.S. and the UK, it was concluded that the right-wing parties care more about inflation, while, the left-wing parties care about unemployment. However, in order to win the elections, political parties often proclaim more or less neutral policy or the policy adjusted to the current situation to win over a middle i.e. median voter. 
In certain areas of the public choice it is not easy to obtain data that would confirm or reject some hypotheses. However, when talking about the use of macroeconomic policy for the purpose of winning the elections, every country has data on inflation and unemployment that can be compared easily. The answer to the question why voters are mostly responsive to changes in inflation and unemployment lies in the fact that they are directly dependent on their change.

For example, inflation is monitored by the population through price changes or their income and measured through changes in their purchasing power. On the other hand, other macroeconomic indicators such as the balance of payments and budget deficits, despite their importance, with a hint of change in terms of economic policy and government competence, are difficult to perceive from the micro level, and therefore voters do not attach great importance to them (compared with the inflation rate and unemployment rate).

When deciding what political party they will vote for at the elections, voters do not show particular loyalty to a certain party (apart from some exceptional cases), and they are conducted by their own interests. Having in mind that citizens do not have identical interests and goals, political parties are also directed towards different interest groups through their policies. Thus, employees with lower qualification and education degree are more sensitive to the possibility of losing their jobs and therefore are more responsive to the policy concerning unemployment. On the other hand, highly educated people with stable jobs do not feel disadvantaged in terms of employment and hence they are more responsive to changes in inflation.

Using a certain macroeconomic policy, politicians always count on myopic voters. According to the Phillips curve theory, governments loose monetary and fiscal policy to reduce unemployment rate and create fast growth, which they believe is helpful in winning votes. Nordhaus (1975) explained this idea of opportunistic behaviour by the "political business cycle" model. Consequently, there is a tendency towards high inflation rate in pre-election period, which the government tries to suppress after elections. To do this, the government contracts the money supply and government's expenditure, resulting in an economic slowdown. This economic business cycle recurs with each electoral cycle (Park, 2011, 118). Castro and Veiga (2004) analysed the behaviour of policymakers regarding the timing of stabilization on the sample of 10 countries that experienced chronic inflation and implemented stabilisation programs covering period from 1957-1999 and confirmed that money-based stabilization plans are more likely to be implemented shortly after elections. However, study by Alesina et al. (1992) on a sample of 18 OECD countries found some evidence of pre-electoral effects of expansionary monetary and fiscal policy on the unemployment and economic growth, which resulted in high inflation after the elections. 
Therefore, some voters are all over again subjected to the tricks of political parties, which adapt their economic policies in order to win the elections. Such voting behaviour can be explained by their desire to believe that the currently proclaimed policy will remain long-termed.

However, the parties cannot always count on myopic voters. It should be noted that one group of them has rational expectations, that they may be well informed or have enough knowledge on how economy works. Suppose we have only two candidates $A$ and $B$, and that voters are well informed. Candidate $A$ is able to achieve increased revenues, but with higher inflation rates. However, if candidate $A$ is in power and may affect the increase in revenue at the cost of accelerating price increase by appropriate macroeconomic policies, voters will vote in his favour at the elections as long as this candidate works better than his political opponents, i.e. while the benefits of such carried out policy are much higher than its consequences, in this case of price increase (Mueller, 2003, 439).

\section{Empirical Results and Discussion}

By examining the relationship between economics and politics in the case of Serbia, it is evident that the elections, among other things, affected the economic situation in the period of elections. However, the problems Serbian economy faced have changed over time, and thus political programmes as well.

Political parties have directed their policies and programmes along with economic problems in order to solve them. Concerning the fact that both theory and practice has confirmed that the population primarily responds to changes in inflation and unemployment, these basic macroeconomic indicators have received the greatest attention.

During the period of high inflation, especially hyperinflation at the end of the $20^{\text {th }}$ century, the efforts of political parties that fought for survival in the political arena were directed to the reduction of prices and maintaining inflation within the limits acceptable for all stable economies.

Although the problem of high inflation is not permanently solved, and bearing in mind that it always recurs to a greater or lesser extent the problem of high unemployment has recently emerged. Therefore, political programmes at the last elections are focused on its solving. The emphasis is placed on attracting investments, creating new jobs, capacity expansion, etc., all with the aim of increasing employment rate.

Counting on myopic voters, by increasing the money supply in the preelection period, GDP is increased with a slight rise in employment. In this way 
the effort to initiate rapid economic growth and achieve overall economic prosperity of the country is proclaimed. However, artificially induced increase in money supply will inevitably lead to higher inflation rates and return of the economy to its common level, in terms of basic indicators of economic development, in the post-election period.

Since parliamentary elections have the greatest effect on the macroeconomic environment of Serbia (because the government creates a macroeconomic policy), we will examine their impact on inflation and unemployment. Table 2 shows the overview of the parliamentary elections since 2000. Data on inflation and unemployment are obtained from databases of the Statistical Office of the Republic of Serbia and National Bank of Serbia.

Table 2. Overview of the parliamentary elections in Serbia in period 2000 2014

Elections for the Members of Parliament of the National Assembly of the Republic of Serbia

\begin{tabular}{|l|l|l|l|l|l|}
\hline 23.12 .2000$. & 28.12 .2003$. & 21.01 .2007$. & 11.05 .2008$. & 06.05 .2012$. & 16.03 .2014$. \\
\hline
\end{tabular}

Source: Statistical Office of the Republic of Serbia

As we can see from Figure 1, after the years of very high inflation rates (20002001), a single-digit inflation rate in the period 2009-2011 seems encouraging. Starting from January 2009 the National Bank of Serbia changed the monetary policy regime to inflation targeting, which resulted in declining inflation trends in subsequent years (Rakic \& Radjenovic, 2013, 112). Inflation targeting was introduced with the aim to ensure the medium-term price stability and the inflation level in the EU (2-3\% annually) (Nikolic, Tepavac, \& Cvijanovic, 2012, 105). However, the inflation rate in 2012 reached $12.2 \%$. During the last two years, i.e. 2013-2014., the rates were below targeted level of $4.0 \pm 1.5 \%$.

Unemployment, on the other hand, is the problem that with minor variations constantly follows Serbian economy. Since 2008 the unemployment rate continuously grew till 2012. According to Zubovic and Nikolic $(2013,65)$ the problem of high unemployment must be incorporated into the comprehensive strategy and cannot be resolved solely with the active labour market policies.

Figure 1 also enables us to compare theory of political business cycle and practice. Namely, during the election period there is a trade-off between inflation and unemployment, with the aim to reduce unemployment since empirical studies have shown that voters are more sensitive to the loss of a job (i.e. unemployment) than to the increase in prices (i.e. inflation). After the elections their values are returned to their initial levels, and so on alternately. 
Rakić B., et al.: Political Cycles' Influence on Inflation and Unemployment

Figure1. Inflation and Unemployment rates in Serbia for the period 1997 2014

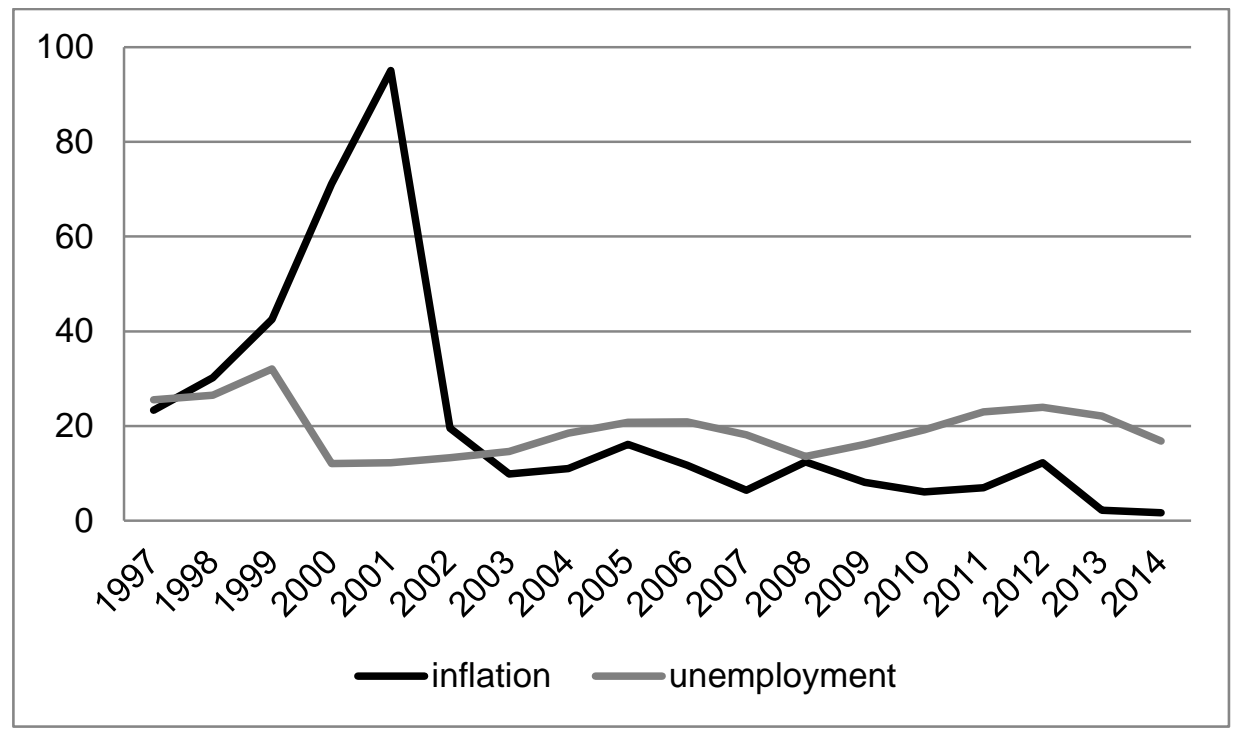

Source: Authors' presentation based on data from National Bank of Serbia and Statistical Office of the RS

The changes, which during the election period manifest in inflation and unemployment, are reflected in the reduction of unemployment rate and the increase in inflation rate, due to their trade-off. Bearing in mind the specific economic and political situation in Serbia in the past two decades, and especially the financial crisis in 2008 , it is difficult to differentiate the influence of political elections. Social situation, economic and political isolation, sanctions influenced on the basic macroeconomic indicators. But even so, in the elections years, the changes could be typically seen in the rates of inflation and unemployment

The adjustment of the indicator values for political purposes is evident in election periods. This confirms the thesis that political and business cycles also exist in Serbia and that political parties use economic policies to achieve their political interests. In addition, commitment to a particular political party is, depending on the macroeconomic policies it supports, influenced by the current economic situation. In the period of high inflation (the beginning of the 2000s), the parties pledging the reduction of inflation through various economic measures had the largest number of supporters. Then again, in the period of high unemployment rate, when the problem of high inflation was solved, the focus of political parties was on its reduction, creation of new jobs 
or at least preservation of the existing ones, attraction of foreign investments, once again in order to increase employment rate.

The graph in Figure 1 shows that high inflation was one of the major economic problems in Serbia at the beginning of the XXI century. However, apart from this, during the elections in 2000, fully in accordance with the political economic cycles, there was a further inflation increase with reduction in the unemployment rate, as well as gradual return of these values to the previous level in 2001. The fluctuations are more distinctive in inflation, which was influenced not only by political elections but also by other economic and political factors.

Similarly, in the election year of 2008 the hypothesis of the political cycles influence can be confirmed through the unemployment reduction and inflation increase. After the election period, the values of the macroeconomic indicators, after being used for achieving political goals, were returned to their prior levels. However, during the elections in 2012 both inflation and unemployment rates recorded annual increase of $5 \%$ and $0.9 \%$, respectively. Conversely, in the election year of 2014 both macroeconomic indicators demonstrated the downward tendency, with inflation reaching $1.7 \%$ and unemployment of $16.8 \%$.

\section{Conclusion}

Understanding the economy and the way it works has always been a primary goal of macroeconomists and economic policy makers. Searching for factors that cause fluctuations and promote cycles, new theories that provide additional explanations of possible causes of the economic (in)stability have been developed. The key question that arises is whether the cycles in economy are caused by real economic shocks or encouraged by political developments.

Public choice, as a relatively young theory, tries to examine the relationship between economics and politics from different perspectives. The fact that individuals are always guided by their own interests (as altruism is rare), represents the connection point between economics and politics, whereas individuals either in economic or in the political sphere are always trying to maximize their own benefit.

Guided by the goal to win the elections and counting on myopic voters, political parties are trying to win the median voter by improving the economic situation. However, voters' attitudes depend on whether they put in the forefront the interests of national economy or their personal (financial) ones; whether their attitudes are more influenced by the results achieved in the 
Rakić B., et al.: Political Cycles' Influence on Inflation and Unemployment

previous mandate or by their expectations related to election promises of political parties, etc.

Despite many difficulties in proving how voters react to the changes in the economy, it is theoretically shown and confirmed in practice by many countries that macroeconomic indicators are manipulated with during the election year (i.e. inflation and unemployment in this case), and therefore their values return to previous levels after the elections.

In the case of Serbia, in the observed period from 1997 to 2014, due to frequent regular and early elections, the impact of the crisis, collapse of the federation, the theoretical hypothesis of adjusting key macroeconomic indicators for the purpose of winning the elections can be clearly confirmed only in the penultimate election cycle (elections in 2008). Namely, unemployment rate was reduced and inflation rate increased in the election year (taking into account the trade-off and the impossibility of a simultaneous decrease of both values), while unemployment rate increased again after the elections.

\section{References}

Alesina, A., Cohen, G. D. and Roubini, N. (1992). Macroeconomic Policy and Elections in OECD Democracies. Economics \& Politics, 4(1), 1-30. DOI:10.1111/j.14680343.1992.tb00052.x.

Buchanan, J. M. (2004). Constitutional Political Economy. In C. K. Rowley \& F. Schneider (Eds.), Encyclopedia of Public Choice, Volume 1 (pp.60-66). Boston, USA: Kluwer Academic Publishers.

Castro, V. and Veigra, F. J. (2004). Political Business Cycles and Inflation Stabilization. Economics Letters, 83, 1-6. DOI: 10.1016/j.econlet.2003.07.016.

Drašković, V. (1998). Suština i značaj teorije javnog izbora. Ekonomska misao, 31(3), 213-222.

Evans, J. A. J. (2003). Voters and Voting: An Introduction. London, UK: SAGE Publications.

Frey, B. S. (1984). The public choice view of international political economy. International Organization, 38, 199 - 223. DOI: 10.1017/S0020818300004318.

Gavious, A. and Mizrahi, S. (2002). Maximizing Political Efficiency via Electoral Cycles: An Optimal Control Model. European Journal of Operational Research, 141(1), 186-199. DOI: 10.1016/S0377-2217(01)00232-6.

Martinez, L. (2009). A Theory of Political Cycles. Journal of Economic Theory, 144(3), 1166-1186. DOI: 10.1016/j.jet.2008.10.006.

Mueller, D. C. (2004). Public Choice: An Introduction. In C. K. Rowley \& F. Schneider (Eds.), Encyclopedia of Public Choice, Volume 1 (pp. 32-48). Boston, USA: Kluwer Academic Publishers.

Mueller, D. C. (2003). Public Choice III. West Nyack, NY, USA: Cambridge University Press.

National bank of Serbia, Retreived from http://www.nbs.rs 
Rakić B., et al.: Political Cycles' Influence on Inflation and Unemployment

Nikolić, A. R., Tepavac, D. \& Cvijanović, J. (2012). Monetary policy and insolvency of economic sector. Industrija, 40(1), 103-131. Retrieved from http://scindeksclanci.ceon.rs/data/pdf/0350-0373/2012/0350-03731201103N.pdf

Nordaus, W. D. (1975). The Political Business Cycle. Review of Economic Studies, 42(2), 169-190. DOI: 10.2307/2296528.

Paldam, M. (2004). Are Vote and Popularity Functions Economically Correct? In C. K. Rowley \& F. Schneider (Eds.), Encyclopedia of Public Choice, Volume 1 (pp. 4959). Boston, USA: Kluwer Academic Publishers.

Rakić, B. \& Radjenović, T. (2013). The Effectiveness of Monetary and Fiscal Policy in Serbia. Industrija - Quarterly Journal of Economics Institute, 41(2), 103-122. DOI: 10.5937/industrija41-4011

Park, J.-H. (2011). The Economy and Elections in Korea: an Analysis of the Political Business Cycle. International Review of Public Administration, 16(2), 117-142. DOI: 10.1080/12264431.2011.10805199

Rogoff, K. (1990). Equilibrium political budget cycles. American Economic Review, 80(1), 21-26. Retrieved from http://scholar.harvard.edu/files/rogoff/files/51 aer90.pdf.

Rowley, C. K. (2004). Public Choice and Constitutional Political Economy. In C. K. Rowley \& F. Schneider (Eds.), Encyclopedia of Public Choice, Volume 1 (pp. 331). Boston, USA: Kluwer Academic Publishers.

Statistical Office of the Republic of Serbia, Retrieved from http://www.stat.gov.rs

Tollison, R. D. (2004). Homo Economicus. In C. K. Rowley \& F. Schneider (Eds.), Encyclopedia of Public Choice, Volume 2 (pp. 281-284). Boston, USA: Kluwer Academic Publishers.

Wu, W. \& Davis, A. O. (2004). Economic Freedom and Political Freedom. In C. K. Rowley \& F. Schneider (Eds.), Encyclopedia of Public Choice, Volume 2 (pp. 163-171). Boston, USA: Kluwer Academic Publishers.

Zubović, J. \& Nikolić, I. (2013). Determining the Effectiveness of ALMP on Youth in Serbia. Industrija, 41(3), 55-66. DOI: 10.5937/industrija41-4762. 